\title{
The Influence of Financial Stressors, Financial Behavior, Risk Tolerance, Financial Solvency, And Financial Knowledge on Financial Satisfaction of Working Age Population
}

\author{
Anisah Firli ${ }^{1}$, Shafira Khairunnisa ${ }^{2}$, Dadan Rahadian ${ }^{3,}$ \\ ${ }^{1,2,3}$ School of Economics and Business, Universitas Telkom, Bandung, Indonesia
}

\begin{abstract}
Financial satisfaction is the ultimate goal of individuals who work hard and manage their finance. Working age is the time when individuals are considered able to work and earn, yet they tend to fail to meet the expected financial satisfaction due to several factors. This research aims to test the influence of financial stressors, financial behavior, risk tolerance, financial solvency, financial knowledge on financial satisfaction. This research includes all important variables (financial stressors, risk tolerance, and financial solvency) that can determine financial satisfaction. The participants in this research were 100 respondents, selected by convenience sampling, from the working-age population in Jakarta, the capital city of Indonesia, who gave the biggest contribution to the economy. The data were analyzed by using multiple linear regression analysis. The findings show that financial stressors, financial behavior, risk tolerance, financial solvency, and financial knowledge simultaneously had a significant influence on financial satisfaction. Partially, only risk tolerance and financial knowledge variables affect financial satisfaction. The findings imply that the working-age population should manage financial stressors, financial behavior, risk tolerance, financial solvency, and financial knowledge properly to improve financial satisfaction reflecting financial welfare.
\end{abstract}

Keywords-Financial stressors; financial behaviour; risk tolerance; financial Solvency; financial knowledge; financial satisfaction.

\begin{abstract}
Abstrak
Financial Satisfaction merupakan dambaan setiap individu dalam menjalani kehidupan atas hasil kerja keras dan perilaku pengaturan keuangan yang dilakukan. Usia produktif merupakan usia dimana seseorang dianggap mampu bekerja dan berpenghasilan, namun terkadang tidak mencapai tingkat kepuasan keuangan sesuai harapan yang disebabkan oleh beberapa faktor. Tujuan penelitian ini bertujuan untuk menguji pengaruh variabel Financial Stressor, Financial Behavior, Risk Tolerance, Financial Solvency, Financial Knowledge terhadap Financial Satisfaction. Penelitian ini memiliki variabel yang sangat lengkap (financial stressors, risk tolerance, dan financial solvency) sebagai penentu financial satisfaction khususnya pada usia produktif. Penelitian ini dilakukan pada 100 responden penduduk usia produktif di ibu kota Indonesia yaitu Jakarta, sebagai kota dengan penyumbang perekonomian terbesar di Indonesia. Teknik pengambilan sampling menggunakan convenience sampling. Teknik analisis data yang digunakan adalah analisis linier berganda. Penelitian ini memberikan kesimpulan bahwa Financial Stressor, Financial Behavior, Risk Tolerance, Financial Solvency, Financial Knowledge secara simultan berpengaruh signifikan terhadap terhadap financial Satisfaction. Sedangkan secara parsial, hanya variabel Risk Tolerance dan Financial knowledge yang berpengaruh terhadap Financial Satisfaction. Penelitian ini memberikan implikasi bahwa penduduk usia produktif harus dapat mengelola Financial Stressor, Financial Behavior, Risk Tolerance, Financial Solvency, Financial Knowledge secara baik sehingga dapat meningkatkan Financial Satisfaction sebagai cerminan kesejahteraan dan kebahagiaan keuangan.
\end{abstract}

Kata kunci-financial stressors; financial behaviour; risk tolerance; financial Solvency; financial knowledge; financial satisfaction; 


\section{INTRODUCTION}

Financial satisfaction indicates the level of satisfaction affected by the financial situation (Chandra \& Memarista, 2015). The working-age population is individuals considered able to work, earn, and produce goods and services required to run the economy (Sukmaningrum \& Imron, 2017). However, the population tends to financial management issues such as lack of financial planning, lack of investment, excessive lifestyle spending, and consumptive behavior, which eventually affect their financial satisfaction (financial.bisnis.com, 2019). A plethora of research reported the influence of financial stressors, financial behavior, risk tolerance, financial solvency, and financial knowledge on financial satisfaction. Ali et al. (2019) and Halim et al. (2015) suggest that financial issues and conditions experienced by individual or their families (financial stressors) affect the financial situation. Furthermore, Chien and Endo (2016) explain that financial behavior plays an important role in determining individual financial satisfaction as they found that individuals properly managing their finance tend to have higher financial satisfaction.

Financial satisfaction is also influenced by how individuals identify options and optimize available resources. Understanding investment and risk tolerance are essential to meet financial satisfaction (Joo and Grable, 2004; Roszkowski \& Grable, 2007). One of the options that individuals can take to meet their financial needs is by borrowing money from individuals, families, or financial institutions (Otoritas Jasa Keuangan, 2016). Halim et al. (2015) define the ability to pay the loan as financial solvency. Failure to close the financial deficit or to apply financial solvency tends to result in financial dissatisfaction. Furthermore, Halim et al. (2015) suggest that financial knowledge, the ability to comprehend, analyze, and manage finance, affect the level of welfare and financial satisfaction.

The previous research on financial satisfaction tends to focus on one independent variable affecting financial satisfaction. This research utilizes a more comprehensive model that analyzes various variables as factors that influence the financial satisfaction of the working-age population in Jakarta, the capital city of Indonesia. Jakarta has the highest gross regional domestic product in Indonesia. The city, which had 7.4 million workingage population (Badan Pusat Statistik, 2019), also had recorded the highest spending in Indonesia. Hence, the research conducted on the population is expected to represent the general picture of Indonesia's working-age population's financial satisfaction.

\section{LITERATURE REVIEW}

\section{A. Financial Stressors}

Financial stressors are dissatisfaction related to needs fulfillment that requires money experienced by individuals (Davis \& Mantler (2004); Halim et al., 2015). The dissatisfaction can be caused by various factors, such as family, friends, and relatives (McCubbin \& Patterson, 1983), or social status (Hayhoe et al., 2000) affecting the psychological and physical health of individuals (Northern et al., 2010; Kim \& Garman, 2003). In addition, Ali et al. (2019) suggest that financial stressors can also affect individuals' family life (Ali et al., 2019). Joo and Grable (2004) explain that measurement of financial stressors requires evaluation of three dimensions, namely (1) personal stressors: investment loss, accident, illness, wage cuts; (2) family stressors: marital status, retirement, birth and mortality, and health; and (3) financial situations: money-related issues such as debts and mortgages.

\section{B. Financial Behavior}

Financial behavior relates to financial organization and management to achieve life goals (Xiao,2008; Ida \& Dwinta, 2010; Falahati, 2012). It includes several steps, namely (1) planning, management, and controlling of funding (Kasmir 2010); (2) management of earning, spending, loan, saving, and protection (Xiao et al., 2016); (3) systematic financial management through savings (Ahmad et al., 2017); and (4) budgeting, credit, and loan management planning (Arifin, 2018). Pratiwi (2019) utilized planning, management, and controlling indicators to measure individuals' financial behavior.

\section{Risk Tolerance}

Risk tolerance measures the extent to which individuals tolerate risks of investments (Bahri, 2018; Dalton \& Dalton, 2004). Investment decisions depend on an individual's risk tolerance, how much risk an individual can bear when making an investment (Rachmawati et al., 2015). As individuals' responses on risks vary 
(Roszkowski \& Grable, 2007), individuals' investment preference varies depending on their risk tolerance (Yip, 2000). Risk tolerance has a positive effect on financial satisfaction, a large individual risk tolerance will increase the level of financial satisfaction (Sherlyani \& Pamungkas, 2020).

\section{Financial Solvency}

Financial solvency is individuals' ability to pay loans (Halim et al., 2015). The ability can be measured by comparing assets in possession and loan. Individuals with high financial solvency, the ability to pay a loan, tend to be satisfied with their financial conditions.

\section{E. Financial Knowledge}

Darmawan and Pamungkas (2019) define financial knowledge as individuals' understanding and knowledge of finance used as the basis of rational financial decision-making and solvency of financial issues (Durband et al., 2019). Financial knowledge is essential for correct financial management as it encourages deep comprehension, analysis, and organization that can prevent individuals from making incorrect financial decisions (Halim et al., 2015).

\section{F. Financial Satisfaction}

As the name suggests, financial satisfaction relates to individuals' satisfaction with their financial conditions (Hasibuan et al., 2017; Chandra \& Memarista, 2015). The satisfaction can be obtained when the necessities and wishes are fulfilled (Falahati et al., 2012). Ali et al. (2015) suggest that the better the financial condition is, the more prosperous individuals' life. Pratiwi (2019) explains that the measurement of financial satisfaction includes several indicators that assess individuals' earning, financial management, and current financial condition. The indicators can show individuals' level of satisfaction related to their financial conditions. According to Hasibuan et al., (2017) financial satisfaction can be measured by looking at how a person manages his income, manages financial problems, determines basic needs, does debt or not, saves ot not, provides savings for the future, and determines life goals.

\section{G. Hypothesis Development}

\section{a) The Influence of financial stressors on financial satisfaction}

A plethora of research on financial stressors and financial satisfaction has been conducted. Joo and Garman (1998) found that individuals dissatisfied with their financial condition have financial stressors. Some researchers (see, for instance, Tharp et al., 2019; Ali et al., 2019; Woodyard \& Robb, 2016) also reported that financial stressors affect financial satisfaction. Hence, the hypothesis is as follows:

H1: Financial stressors has a significant influence on financial satisfaction of the working-age population

\section{b) The influence of financial behavior on financial satisfaction}

Some researchers (see, for example, Coskuner 2016; Arifin, 2018; Hasibuan et al., 2017; Darmawan et al., 2019; Pratiwi, 2019) found that financial behavior has a significant influence on financial satisfaction. Hence, the hypothesis is as follows:

H2: Financial behavior has a significant influence on financial satisfaction of the working-age population

\section{c) The influence of risk tolerance on financial satisfaction}

The research conducted by Pratiwi (2019) indicates that risk tolerance has a significant influence on financial satisfaction. Hence, the hypothesis is as follows:

H3: Risk tolerance has a significant influence on financial satisfaction of the working-age population

\section{d) The influence of financial solvency on financial satisfaction}

According to Halim et al. (2015), financial solvency has a significant influence on financial satisfaction. Individuals experiencing financial deficits tend to be dissatisfied with their financial conditions. Hence, the hypothesis is as follows:

H4: Financial solvency has a significant influence on financial satisfaction of the working-age population 


\section{e) The influence of financial knowledge on financial satisfaction}

Some researchers (see, for example, Pratiwi, 2019; Ali et al., 2019; Darmawan \& Pamungkas, 2019) found that financial knowledge significantly influences financial satisfaction. Hence, the hypotheses are as follows:

H5: Financial knowledge has a significant influence on financial satisfaction of the working-age population

H6: Financial stressors, financial behavior, risk tolerance, financial solvency, financial knowledge simultaneously have a significant influence on financial satisfaction of the working-age population.

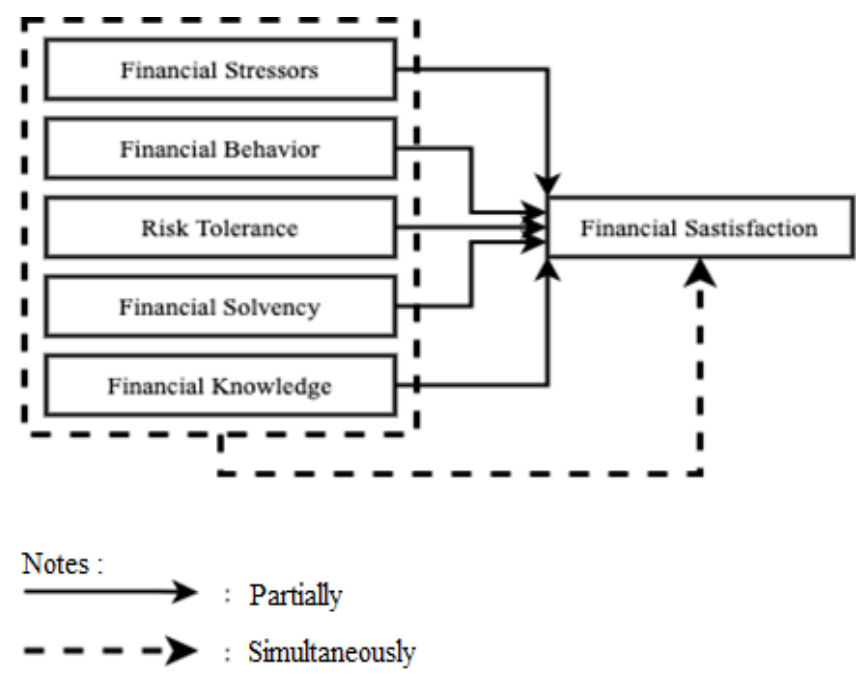

Figure 1. Research Framework (Source: Halim et al., 2015)

\section{RESEARCH METHODOLOGY}

There are five independent variables and one dependent variable in this research. The data collection involves distributing questionnaires to 100 respondents who the working-age population in Jakarta. Purposive (convenience) sampling was utilized to select the respondents, and the Slovin method was utilized to determine the number of respondents.

Table 1. Research Variables

\begin{tabular}{llll}
\hline \multicolumn{1}{c}{ Variables } & \multicolumn{1}{c}{ Sub-Variables } & \multicolumn{1}{c}{ Indicators } & Scale \\
\hline Financial Stressors (X1) & Personal (X1.1) & Investment loss & Ordinal \\
(Joo \& Grabel, 2004) & & Accident & Ordinal \\
& & Wage cuts & Ordinal \\
& Family $(X 1.2)$ & Marital status & Ordinal \\
& & Retirement & Ordinal \\
& & Birth and mortality & Ordinal \\
& & Health & Ordinal \\
& Financial Situation $(X 1.3)$ & Debt & Ordinal \\
Financial Behavior (X2) & Planning (X2.1) & Budgeting & Ordinal \\
(Pratiwi, 2019) & & Emergency fund budgeting & Ordinal \\
& & Investment & Ordinal \\
& Management (X2.2) & Saving & Ordinal \\
& & Paying bill on time & Ordinal \\
\hline
\end{tabular}

The respondents were required to fill questionnaires with a four-option ordinal scale to measure the six variables in this research. The data then were analyzed by linear continuum analysis with the following criteria: 
Table 2. Percentage Range Classification

\begin{tabular}{ccc}
\hline No. & Percentage & Classification \\
\hline 1 & $25 \%-43.75 \%$ & Very Bad \\
2 & $>43.75 \%-62.5 \%$ & Bad \\
3 & $>62.5 \%-81.25 \%$ & Good \\
4 & $>81.25 \%-100 \%$ & Very Good \\
\hline
\end{tabular}

Subsequently, the classic assumption tests (normality, autocorrelation, multicollinearity, and heteroscedasticity) were conducted, followed by multiple linear regression analysis.

\section{RESULT AND DISCUSSION}

\section{A. Result}

Validity and reliability test using were conducted on 30 respondents. The Pearson Product Moment (Siregar, 2013: 48) measurement indicated that all questionnaire items are valid, and Alpha Cronbach (Sujaweni, 2015: 110) showed that the items were reliable.

Based on age, $42 \%$ of the respondents were 25-35 years old, $40 \%$ were 15-24 years old, $9 \%$ were $35-44$ years old, $8 \%$ were $45-54$ years old, and 1\% were 55-64 years old. Based on gender, 59\% of respondents were men, and $41 \%$ were women. In terms of educational background, $59 \%$ of respondents had a bachelor/diploma 4 degree, $16 \%$ had a senior high school diploma, $13 \%$ had a diploma 3 degree, and $12 \%$ had a master degree. In terms of monthly income, $40 \%$ of the respondents earned more than Rp.10,000,000,-, $28 \%$ earned Rp.5,000,0001-Rp.10,000,000,-, $29 \%$ earned Rp.1,000,000,-Rp.5,000,000,-, and 3\% earned less than Rp.1000.000,-. Finally, based on occupation, $45 \%$ of the respondents were employees, $37 \%$ were civic servants, $12 \%$ were tertiary students, $3 \%$ were entrepreneurs, and $3 \%$ had other occupations.

Table 3. Respondents' Responses to Financial Stressors Issues

\begin{tabular}{|c|c|c|c|c|c|c|c|c|c|c|c|}
\hline \multirow{2}{*}{ Statements } & \multicolumn{4}{|c|}{ Responses } & \multicolumn{4}{|c|}{ Scales } & \multirow{2}{*}{$\begin{array}{l}\text { Total } \\
\text { Score }\end{array}$} & \multirow{2}{*}{$\begin{array}{l}\text { Ideal } \\
\text { Score }\end{array}$} & \multirow{2}{*}{$\left(\frac{\text { Total Score }}{\text { Ideal Score }}\right)$} \\
\hline & STS & $\mathrm{TS}$ & $S$ & SS & 1 & 2 & 3 & 4 & & & \\
\hline $\begin{array}{l}\text { Investment loss puts under in stress and } \\
\text { financial difficulty }\end{array}$ & 6 & 27 & 53 & 14 & 6 & 54 & 159 & 56 & 275 & 400 & $68.75 \%$ \\
\hline $\begin{array}{l}\text { Accident puts me under stress and financial } \\
\text { difficulty }\end{array}$ & 9 & 22 & 54 & 15 & 9 & 44 & 162 & 60 & 275 & 400 & $68.75 \%$ \\
\hline $\begin{array}{l}\text { Wage cuts put me under stress and financial } \\
\text { difficulty }\end{array}$ & 5 & 19 & 50 & 26 & 5 & 38 & 150 & 104 & 297 & 400 & $74.25 \%$ \\
\hline $\begin{array}{l}\text { Marriage puts me under stress and financial } \\
\text { difficulty }\end{array}$ & 32 & 49 & 13 & 6 & 32 & 98 & 39 & 24 & 193 & 400 & $48.25 \%$ \\
\hline $\begin{array}{l}\text { Divorce puts me under stress and financial } \\
\text { difficulty }\end{array}$ & 16 & 41 & 28 & 15 & 16 & 82 & 84 & 60 & 242 & 400 & $60.50 \%$ \\
\hline $\begin{array}{l}\text { I am not ready to retire and retirement puts me } \\
\text { under stress and financial difficulty }\end{array}$ & 10 & 15 & 35 & 40 & 10 & 30 & 105 & 160 & 305 & 400 & $76.25 \%$ \\
\hline $\begin{array}{l}\text { Birth of a baby puts me under stress and } \\
\text { financial difficulty }\end{array}$ & 36 & 40 & 17 & 7 & 36 & 80 & 51 & 28 & 195 & 400 & $48.75 \%$ \\
\hline $\begin{array}{l}\text { Death of a family member puts me under stress } \\
\text { and financial difficulty }\end{array}$ & 27 & 45 & 15 & 13 & 27 & 90 & 45 & 52 & 214 & 400 & $53.50 \%$ \\
\hline $\begin{array}{l}\text { Medical bills put me under stress and financial } \\
\text { difficulty }\end{array}$ & 17 & 22 & 45 & 16 & 17 & 44 & 135 & 64 & 260 & 400 & $65.00 \%$ \\
\hline $\begin{array}{l}\text { Debt puts me under stress and financial } \\
\text { difficulty }\end{array}$ & 6 & 15 & 36 & 43 & 6 & 30 & 108 & 172 & 316 & 400 & $79.00 \%$ \\
\hline Financial Stressors Variable Percentage & & & & & & & & & & & $64.30 \%$ \\
\hline
\end{tabular}


Table 4. Respondents' Responses to Financial Behavior Issues

\begin{tabular}{|c|c|c|c|c|c|c|c|c|c|}
\hline \multirow{2}{*}{ Statements } & \multicolumn{3}{|c|}{ Responses } & \multicolumn{3}{|c|}{ Scales } & \multirow{2}{*}{$\begin{array}{l}\text { Total } \\
\text { Score }\end{array}$} & \multirow{2}{*}{$\begin{array}{l}\text { Ideal } \\
\text { Score }\end{array}$} & \multirow{2}{*}{$\left(\frac{\text { Total Score }}{\text { Ideal Score }}\right)$} \\
\hline & STS & $\mathrm{TS}$ & $\mathrm{S}$ & SS 12 & 3 & 4 & & & \\
\hline I make a budget planning & 4 & 13 & 47 & 36426 & 141 & 144 & 315 & 400 & $78.75 \%$ \\
\hline I have emergency funds & 1 & 11 & 50 & 38122 & 150 & 152 & 325 & 400 & $81.25 \%$ \\
\hline I invest to manage my finance & 4 & 29 & 40 & 27458 & 120 & 108 & 290 & 400 & $72.50 \%$ \\
\hline I save money periodically or regularly & 1 & 10 & 50 & 39120 & 150 & 156 & 327 & 400 & $81.75 \%$ \\
\hline I pay bills on time & 1 & 4 & 49 & 4618 & 147 & 184 & 340 & 400 & $85.00 \%$ \\
\hline $\begin{array}{l}\text { I compare prices of goods and services before } \\
\text { making a purchase }\end{array}$ & 0 & 4 & 37 & $\begin{array}{lll}59 & 0 & 8\end{array}$ & 111 & 236 & 355 & 400 & $88.75 \%$ \\
\hline I record my income and spending & 6 & 20 & 43 & 31640 & 129 & 124 & 299 & 400 & $74.75 \%$ \\
\hline Financial Behavior Variable Percentage & & & & & & & & & $80.39 \%$ \\
\hline
\end{tabular}

Table 5. Respondent's Responses to Risk Tolerance Issues

\begin{tabular}{|c|c|c|c|c|c|c|c|c|c|c|c|}
\hline \multirow{2}{*}{ Statements } & \multicolumn{4}{|c|}{ Responses } & \multicolumn{4}{|c|}{ Scales } & \multirow{2}{*}{$\begin{array}{l}\text { Total } \\
\text { Score }\end{array}$} & \multirow{2}{*}{$\begin{array}{l}\text { Ideal } \\
\text { Score }\end{array}$} & \multirow{2}{*}{$\left(\frac{\text { Total Score }}{\text { Ideal Score }}\right)$} \\
\hline & STS & $\mathrm{TS}$ & $\mathrm{S}$ & SS & 1 & 2 & 3 & 4 & & & \\
\hline $\begin{array}{l}\text { I think that investment security is more } \\
\text { important than profits }\end{array}$ & 1 & 14 & 41 & 44 & 1 & 281 & 1231 & 176 & 328 & 400 & $82.00 \%$ \\
\hline I tend to associate risk with loss & 9 & 24 & 38 & 29 & 92 & 481 & 1141 & 116 & 287 & 400 & $71.75 \%$ \\
\hline $\begin{array}{l}\text { I prefer investing in bank savings than } \\
\text { stock markets }\end{array}$ & 9 & 23 & 39 & 29 & 92 & 461 & 1171 & 116 & 288 & 400 & $72.00 \%$ \\
\hline $\begin{array}{l}\text { I invest on stocks and bonds only based } \\
\text { on projected profits }\end{array}$ & 14 & 37 & 35 & 14 & 147 & 741 & 105 & 56 & 249 & 400 & $62.25 \%$ \\
\hline Risk Tolerance Variable Percentage & & & & & & & & & & & $72.00 \%$ \\
\hline
\end{tabular}

Table 6. Respondent's Responses to Financial Solvency Issues

\begin{tabular}{lccccccccccccc}
\hline \multirow{2}{*}{ Statements } & \multicolumn{4}{c}{ Responses } & \multicolumn{4}{c}{ Scales } & & Total & Ideal \\
\cline { 2 - 10 } & & STS & TS & S & SS & 1 & 2 & 3 & 4 & Score & Score & $\left(\frac{\text { Tot Score }}{\text { Ideal Score }}\right)$ \\
\hline I manage to pay my debts & 0 & 3 & 49 & 48 & 0 & 6 & 147 & 192 & 345 & 400 & $86.25 \%$ \\
\hline Financial Solvency Variable Percentage & & & & & & & & & & & $86.25 \%$ \\
\hline
\end{tabular}

Table 7. Respondent's Responses to Financial Knowledge Issues

\begin{tabular}{|c|c|c|c|c|c|c|c|c|c|c|c|}
\hline \multirow{2}{*}{ Statements } & \multicolumn{4}{|c|}{ Responses } & \multicolumn{4}{|c|}{ Scales } & \multirow{2}{*}{$\begin{array}{l}\text { Total } \\
\text { Score }\end{array}$} & \multirow{2}{*}{$\begin{array}{l}\text { Ideal } \\
\text { Score }\end{array}$} & \multirow{2}{*}{$\left(\frac{\text { Total Score }}{\text { Ideal Score }}\right.$} \\
\hline & STS & TS & $\mathrm{S}$ & SS & 1 & 2 & 3 & 4 & & & \\
\hline I understand investment & 3 & 31 & 46 & 20 & 3 & 62 & 138 & 80 & 283 & 400 & $70.75 \%$ \\
\hline $\begin{array}{l}\text { I understand personal financial } \\
\text { management }\end{array}$ & 0 & 9 & 59 & 32 & 0 & 18 & 177 & 128 & 323 & 400 & $80.75 \%$ \\
\hline I understand financial recording & 1 & 11 & 59 & 29 & 1 & 22 & 177 & 116 & 316 & 400 & $79.00 \%$ \\
\hline Financial Knowledge Variable Percentage & & & & & & & & & & & $76.83 \%$ \\
\hline
\end{tabular}


Table 8. Respondent's Responses to Financial Satisfaction Issues

\begin{tabular}{|c|c|c|c|c|c|c|c|c|c|c|c|}
\hline \multirow{2}{*}{ Statements } & \multicolumn{4}{|c|}{ Responses } & \multicolumn{4}{|c|}{ Scales } & \multirow{2}{*}{$\begin{array}{l}\text { Total } \\
\text { Score }\end{array}$} & \multirow{2}{*}{$\begin{array}{l}\text { Ideal } \\
\text { Score }\end{array}$} & \multirow{2}{*}{$\left(\frac{\text { Total Score }}{\text { Ideal Score }}\right)$} \\
\hline & STS & $\mathrm{TS}$ & $\mathrm{S}$ & SS & 1 & 2 & 3 & 4 & & & \\
\hline I am satisfied with my earnings & 7 & 23 & 54 & 16 & 7 & 46 & 162 & 64 & 279 & 400 & $69.75 \%$ \\
\hline $\begin{array}{l}\text { I am satisfied with my financial } \\
\text { management skills }\end{array}$ & 3 & 25 & 60 & 12 & 3 & 50 & 180 & 48 & 281 & 400 & $70.25 \%$ \\
\hline $\begin{array}{l}\text { I am satisfied with my current financial } \\
\text { conditions }\end{array}$ & 9 & 27 & 52 & 12 & 9 & 54 & 156 & 48 & 267 & 400 & $66.75 \%$ \\
\hline I am satisfied with my purchasing power & 4 & 21 & 60 & 15 & 4 & 42 & 180 & 60 & 286 & 400 & $71.50 \%$ \\
\hline $\begin{array}{l}\text { I am satisfied with my current savings, } \\
\text { pension funds, and emergency funds }\end{array}$ & 9 & 40 & 42 & 9 & 9 & 80 & 126 & 36 & 251 & 400 & $62.75 \%$ \\
\hline Financial Satisfaction Variable Percentage & & & & & & & & & & & $68.20 \%$ \\
\hline
\end{tabular}

Table 9. Determination Coefficient

\begin{tabular}{cccccc}
\hline Model & $\mathrm{R}$ & $\mathrm{R}$ Square & Adjusted R Square & Std. Error of the Estimate & Durbin-Watson \\
\hline 1 & $.548^{\mathrm{a}}$ & .301 & .263 & 3.177032 & 2.209 \\
\hline aPredictors: (Constant), Financial Knowledge, Financial Stressors, Financial Solvency, Risk Tolerance, Financial Behavior
\end{tabular}

Table 10. The results of Multiple Linear Regression Analysis of all Variables

\begin{tabular}{|c|c|c|c|c|c|c|}
\hline & \multirow{2}{*}{ Model } & \multicolumn{2}{|c|}{ Unstandardized Coefficients } & \multirow{2}{*}{$\begin{array}{c}\text { Standardized Coefficients } \\
\text { Beta }\end{array}$} & \multirow{2}{*}{$\mathrm{T}$} & \multirow{2}{*}{ Sig. } \\
\hline & & $\mathrm{B}$ & Std. Error & & & \\
\hline \multirow{6}{*}{1} & (Constant) & 2.671 & 3.389 & & .788 & .433 \\
\hline & Financial_Stressor & -.005 & .060 & -.009 & -.087 & .931 \\
\hline & Financial_Behavior & -.034 & .105 & -.039 & -.326 & .745 \\
\hline & Risk_Tolerance & .410 & .134 & .307 & 3.057 & .003 \\
\hline & Financial_Solvency & .679 & .416 & .155 & 1.630 & .106 \\
\hline & Financial_Knowledge & .511 & .203 & .320 & 2.520 & .013 \\
\hline
\end{tabular}

Based on the data processing in table 10, the following multiple linear regression equation is obtained.

$$
Y=2.671-0.005 X_{1}-0.034 X_{2}+0.410 X_{3}+0,679 X_{4}+0.511 X_{5}
$$

Captions :

$\begin{array}{ll}\mathrm{Y} & =\text { Financial Satisfaction } \\ \mathrm{b}_{0} & =\text { Constant Coefficient } \\ \mathrm{X}_{1} & =\text { Financial Stressors } \\ \mathrm{X}_{2} & =\text { Financial Behavior } \\ \mathrm{X}_{3} & =\text { Risk Tolerance } \\ \mathrm{X}_{4} & =\text { Financial Solvency } \\ \mathrm{X}_{5} & =\text { Financial Knowledge }\end{array}$

Table 11. The Result of Simultaneous Hypothesis Tests (F Test)

\begin{tabular}{rlrrrrr}
\hline Model & & Sum of Squares & \multicolumn{1}{c}{ df } & Mean Square & F & Sig. \\
\hline \multirow{3}{*}{1} & Regression & 407.777 & 5 & 81.555 & 8.080 & $.000^{\mathrm{b}}$ \\
& Residual & 948.792 & 94 & 10.094 & & \\
\cline { 2 - 7 } & Total & 1356.569 & 99 & & & \\
\hline
\end{tabular}


Table 12. The result of the partial hypothesis testing (t-test) of all variable

\begin{tabular}{|c|c|c|c|c|c|c|c|}
\hline \multirow{2}{*}{\multicolumn{2}{|c|}{ Model }} & \multicolumn{2}{|c|}{$\begin{array}{c}\text { Unstandardized } \\
\text { Coefficients }\end{array}$} & \multirow{2}{*}{$\begin{array}{l}\text { Standardized } \\
\text { Coefficients } \\
\text { Beta } \\
\end{array}$} & \multirow[t]{2}{*}{$\mathrm{t}$} & \multirow[t]{2}{*}{ Sig. } & \multirow[t]{2}{*}{ Findings } \\
\hline & & B & Std. Error & & & & \\
\hline \multirow[t]{6}{*}{1} & (Constant) & 2.671 & 3.389 & & .788 & .433 & \\
\hline & Financial_Stressor & -.005 & .060 & -.009 & -.087 & .931 & Ho accepted \\
\hline & Financial_Behavior & -.034 & .105 & -.039 & -.326 & .745 & Ho accepted \\
\hline & Risk_Tolerance & 410 & .134 & 307 & 3.057 & .003 & Ho rejected \\
\hline & Financial_Solvency & 679 & .416 & .155 & 1.630 & .106 & Ho accepted \\
\hline & Financial_Knowledge & .511 & .203 & 320 & 2.520 & .013 & Ho rejected \\
\hline
\end{tabular}

\section{B. Discussion}

The questionnaires indicate that responses to five variables (financial stressors, financial behavior, risk tolerance, financial knowledge, and financial knowledge) were in the 'good category,' while one variable, financial solvency, was in the 'very good category'.

Financial stressors of the working-age population in Jakarta were in the 'good' category (64.3\%). Most of the respondents had financial stressors in terms of wage cuts, retirement preparation, and debts. The financial behavior of the working-age population in Jakarta was also in the 'good' category (72.5\%). However, the financial behavior has not been ideal as most of the respondents (81\%) preferred to save than invest their money. Some respondents also stated that they did not record their income and spending. Similarly, the risk tolerance of the working-age population in Jakarta was in the 'good' category, although some items indicate that the respondents only invest in stocks and bonds based on projected profits. In terms of financial solvency, the responses indicated that it was in the 'very good' category, indicating that the respondents could manage and pay their debts properly. Furthermore, despite the need to improve investment knowledge, respondents' financial knowledge was in the 'good' category. Lastly, the respondents' financial satisfaction was barely in the 'good' category, as the score was slightly above the threshold $(71.5 \%)$. The finding indicates that the workingage population in Jakarta has not been satisfied with their earnings, financial management skills, current financial conditions, purchasing powers, and the amount of their savings.

The classical assumption tests result indicate that the data were distributed normally, and autocorrelation, multicollinearity, and heteroscedasticity are not found. Regression analysis indicates the total influence of $26.3 \%$, with $73.7 \%$ of influence came from variables beyond the research (See Table 4).

Table 10 indicates a linear, directly proportional association between financial satisfaction and financial behavior, risk tolerance, financial solvency, and financial knowledge. In contrast, financial satisfaction tended to be inversely proportional to financial stressors. In other words, the higher the level of financial behavior, risk tolerance, financial solvency, and financial knowledge of individuals are, the higher their financial satisfaction is. The lower the financial stressors are, the higher the financial satisfaction is.

Table 11 indicates that the significance value (sig.) was lower than 0.05 ; thus, $H_{0}$ is rejected. The finding indicates a significant influence of independent variables (financial stressors, financial behavior, risk tolerance, financial solvency, and financial knowledge) on the dependent variable (financial satisfaction).

Table 12 indicates that the t-test indicates that partially, only risk tolerance and financial variables had a significant influence on financial satisfaction of the working-age population in Jakarta. Other variables, financial stressors, financial behavior, and financial solvency, do not significantly influence financial satisfaction.

\section{CONCLUSION}

Financial stressors, financial behavior, risk tolerance, financial solvency, and financial knowledge simultaneously had a significant influence on financial satisfaction. Partially, only risk tolerance and financial knowledge had a significant influence on financial satisfaction. Nevertheless, based on the simultaneous test, the working-age population in this research were considered able to properly manage financial stressors, financial behavior, risk tolerance, financial solvency, and financial knowledge to improve their financial satisfaction representing welfare and financial happiness. To improve financial satisfaction, this research suggests the 
working-age population in Jakarta to: (1) prepare emergency funds, pension funds and minimize debts that can lead to a high level of stress; (2) search for additional income such as side business and invest money in various financial instruments; (3) manage the risk tolerance of investment products such as deposit and bonds; and (4) actively update knowledge on financial management. This study uses five independent variables, then it is expected to use other variables that can affect financial satisfaction. The method used in this case is the quantitative methods which result in no significant effect between financial behavior and financial satisfaction. Further research is expected to use qualitative methods by conducting interviews. Another limitation in this study is that the majority of respondents almost 82 percent are aged 25-35 years. Meanwhile, for other age categories, the percentage is very small, so for the next research it is necessary to balance between ages so that sample representation can be better

\section{REFERENCE}

Ahmad, K. A., Hasan, R., and Idris, F. (2017). Influence of Financial Literacy on Financial Satisfaction with Financial Behavior as Moderating Variable. Asian Journal of Technical Vocational Education and Training (AJTVET), 2, 1-9.

Ali, A., Rahman, M. S. A., \& Bakar, A. (2015). Financial Satisfaction and The Influence of Financial Literacy in Malaysia. Social Indicators Research, 120(1), 137-156.

Ali, W., Javaid, R., Ali, S., Akram, Y., Ul Haq, A. (2019). Influence of life event on the financial satisfaction of individuals. Journal of Business Studies, 15(1), 123-137.

Arifin, A. Z. (2018). Influence of Financial Attitude, Financial Behavior, Financial Capability on Financial Satisfaction. Advances in Social Science, Education, and Humanities Research (ASSEHR), 186, 100-103.

Arifin, A. Z. (2018). Influence Factor Toward Financial Satisfaction with Financial Behavior as Intervening Variable in Jakarta area Workforce. European Research Studies Journal, 21(1), 90-103.

Badan Pusat Statistika. (2019). Rata-rata Pengeluaran Perkapita Sebulan Menurut Provinsi (Rupiah) 20162018, [online]. https://www.bps.go.id/statictable/2014/09/08/945/rata-rata-pengeluaran-per-kapitasebulan-di-daerah-perkotaan-dan-perdesaan-menurut-provinsi-dan-kelompok-barang-rupiah-20112018.html. [January 2020].

Badan Pusat Statistika. (2019). Produk Domestik Regional Bruto Atas Dasar Harga Konstan 2010 Menurut Provinsi, 2010-2018 (Milyar Rupiah), [online]. https://www.bps.go.id/dynamictable/2015/10/07/956/seri-2010-produk-domestik-regional-bruto-atas-dasar-harga-konstan-2010-menurut-provinsi-2010-2018miliar-rupiah-.html. [January 2020].

Badan Pusat Statistika Provinsi DKI Jakarta. (2019). Jumlah Penduduk Provinsi DKI Jakarta Menurut Kelompok dan Umur Kelamin 2018, [online]. https://jakarta.bps.go.id/dynamictable/2019/09/16/58/jumlah-penduduk-provinsi-dki-jakarta-menurutkelompok-umur-dan-jenis-kelamin-2018-.html. [November 2019].

Bahri, Syaiful. (2018). Metode Penelitian Bisnis - Lengkap dengan Teknik Pengolahan Data SPSS. Yogyakarta: ANDI.

Chandra, J. W., dan Memarista, G. (2015). Faktor-faktor yang mempengaruhi Financial Satisfaction pada Mahasiswa Universitas Kristen Petra. FINESTA, Vol. 3, No.2, 1-6.

Dalton, Michael A. and James F. Dalton. (2004). Personal financial planning: Theory and Practice. Kaplan Financial.

Darmawan, D., \& Pamungkas, A. S. (2019). Pengaruh Financial Attitude, Financial Bahvior, dan Financial Knowledge terhadap Financial Satisfaction. Jurnal Manajerial dan Kewirausahaan, 1(2), 172-181.

Davis, C. G., \& Mantler, J. (2004). The Consequences of Financial Stress for Individuals, Families, and Society [online].https://www.researchgate.net/publication/229052873_The_Consequences_of_Financial_Stress_f or_Individuals_Families_and_Society [8 February 2020].

Durband, D. B., Law, R. H., and Mazzolini, A. K. (2019). Financial Counseling. Springer Nature Switzerland AG 2019. 
Falahati, L., Sabri, M.F. and Paim, L.H. (2012). Assessment of a model of financial satisfaction predictors: examining the mediate effect of financial behaviour and financial strain. World Applied Sciences Journal, 20(2), 190-197.

Halim, Yopie Kurnia Erista \& Astuti, Dewi. (2015). Financial Stressors, Financial Behavior, Risk Tolerance, Financial Solvency, Financial Knowledge, dan Kepuasan Finansial. FINESTA, 3(1), 19-23.

Hasibuan, B. K., HR, W. A., Lubis, M. Y. (2017). Financial Literacy and Financial Behavior as a Measure of Financial Satisfaction. Advance in Economics, Business, and Management Research (AEBMR), 46, 503507.

Hayhoe, C., Leach, L., Turner, P., Bruin, M., \& Lawrence, F. (2000). Differences in spending habits and credit use of college students. The Journal of Consumer Affairs, 34(1), 113- 133.

Ida \& Dwinta, C. Y. (2010). Pengaruh Locus of Control, Financial Knowledge, Income terhadap Financial Management Behavior. Jurnal Bisnis dan Akuntansi, 12(3), 131-144.

Joo, S.-h., \& Garman, E. T. (1998). Personal financial wellness may be the missing factor in understanding and reducing worker absenteeism. Personal Finances and Worker Productivity, 2(2), 172-182.

Joo, S.-h., \& Grable, J. E. (2004). An Exploratory Framework of the Determinants of Financial Satisfaction. Journal of Family and Economic Issues, 25(1), 25-50.

Kasmir. (2010). Pengantar Manajemen Keuangan. Jakarta: Kencana Prenada Media Grup.

Kim, J., \& Garman, E. T. (2003). Financial Stress and Absenteeism: An Empirically. Derived Model. Journal of Financial Counseling and Planning, 14(1), 31.

McCubbin, H. I., \& Patterson, J. M. (1983). The family stress process: The double ABCX model of adjustment and adaptation. Marriage \& family review, 6(1-2), 7-37.

Northern, J. J., O’Brien, W. H., \& Goetz, P. W. (2010). The development, evaluation, and validation of a financial stress scale for undergraduate students. Journal of College Student Development, 51(1), 79-92.

Pratiwi, O. (2019). Pengaruh Financial Knowledge, Financial Behavior, Financial Efficacy, \& Risk Tolerance terhadap Financial Satisfaction pada Pegawai PT. Bank Mandiri (Persero) Kantor Pusat. Jurnal Dinamika Bisnis dan Manajemen, 2(2), 1-11.

Roszkowski, M. J., \& Grable, J. E. (2007). How are Income and Net Worth related to Happiness?. Journal of Financial Service Professionals, Multiple Pages.

Sherlyani, M., \& Pamungkas, A., S. (2020). Pengaruh Financial Behavior, Risk Tolerance, dan Financial Strain Terhadap Financial Satisfaction. Jurnal Manajerial dan Kewirausahaan, II (1), 272-281.

Siregar, S. (2013). Metode Penelitian Kuantitatif Dilengkapi dengan Perbandingan Perhitungan Manual dan SPSS. Jakarta: KENCANA.

Sukmaningrum, A., dan Imron, A. (2017). Manfaat Usia Produktif dengan Usaha Kreatif Industri Pembuatan Kaos pada Remaja di Gresik. Paradigma. 5(3).

Xiao, J. J. (2008). Applying Behavior Theories to Financial Behavior. Handbook of Consumer Finance Research, 69-81.

Xiao, J. J., dan O’Neill, B. (2016). Financial education and financial capability. International Journal of Consumer Studies.

Yip, U. Y. (2000). Financial risk tolerance: a state or a trait?. (Master's Thesis, University of New South Wales). 